University of Nebraska - Lincoln

DigitalCommons@University of Nebraska - Lincoln

Other Publications in Zoonotics and Wildlife

Disease

Wildlife Disease and Zoonotics

1999

\title{
Family Cluster of Rocky Mountain Spotted Fever
}

James E. Childs

Centers for Disease Control and Prevention, Atlanta, james.childs@yale.edu

Timothy F. Jones

Allen S. Craig

Christopher D. Paddock

Don B. McKechnie

See next page for additional authors

Follow this and additional works at: https://digitalcommons.unl.edu/zoonoticspub

Part of the Veterinary Infectious Diseases Commons

Childs, James E.; Jones, Timothy F.; Craig, Allen S.; Paddock, Christopher D.; McKechnie, Don B.; Zaki, Sherif R.; and Schaffner, William, "Family Cluster of Rocky Mountain Spotted Fever" (1999). Other Publications in Zoonotics and Wildlife Disease. 56.

https://digitalcommons.unl.edu/zoonoticspub/56

This Article is brought to you for free and open access by the Wildlife Disease and Zoonotics at DigitalCommons@University of Nebraska - Lincoln. It has been accepted for inclusion in Other Publications in Zoonotics and Wildlife Disease by an authorized administrator of DigitalCommons@University of Nebraska - Lincoln. 
Authors

James E. Childs, Timothy F. Jones, Allen S. Craig, Christopher D. Paddock, Don B. McKechnie, Sherif R. Zaki, and William Schaffner 


\section{Family Cluster of Rocky Mountain Spotted Fever}

Timothy F. Jones, Allen S. Craig, Christopher D. Paddock, Don B. McKechnie, James E. Childs, Sherif R. Zaki, and William Schaffner
From the Epidemic Intelligence Service, Epidemiology Program Office, the Viral and Rickettsial Zoonoses Branch, and the Infectious Disease Pathology Activity, Centers for Disease Control and Prevention, Atlanta, Georgia; and the Tennessee Department of Health, and the Departments of Preventive Medicine and Medicine, Vanderbilt University School of Medicine, Nashville, Tennessee

Soon after a patient from Tennessee died of Rocky Mountain spotted fever (RMSF), several family members developed symptoms suggestive of the disease and were treated presumptively for RMSF. Fifty-four persons visiting the index patient's home were interviewed; serum samples were collected from 35. Three additional cases of RMSF were confirmed, all of which occurred in firstdegree relatives. Time spent at the family home and going into the surrounding woods were significantly associated with developing antibodies to Rickettsia rickettsii. Ticks were collected and examined for rickettsiae by polymerase chain reaction analysis. Because hyperendemic foci and family clusters of RMSF can occur, when a case is suspected clinicians should be vigilant for signs and symptoms consistent with $R$. rickettsii infection in other persons who may have been similarly exposed.

Indeed, one of the characteristic features of the disease. . . is the rare occurrence of more than one case in a given family during a season. . . .

$$
\text { — Howard T. Ricketts, } 1909 \text { [1] }
$$

Rocky Mountain spotted fever (RMSF) is a tick-borne disease caused by Rickettsia rickettsii, the case-fatality ratio for which approaches $25 \%$ if untreated. Despite the availability of effective antibiotic therapy, the case-fatality ratio has remained at $4 \%$ to $10 \%$ since the $1950 \mathrm{~s}$ [2-4]. The number of reported cases of RMSF in the United States has steadily increased over the past 5 years, and in 1996, cases were at their highest levels in over a decade [5]. Eighty-two percent of reported cases occurred in the South Atlantic and south central regions, with $<2 \%$ of cases reported from the mountain states [5].

Although typically considered a sporadic disease, familial clusters of RMSF have been reported occasionally [6-11]. There have also been reports of foci ("islands") of disease hyperendemicity [12-21]. These foci have encompassed regions as large as entire counties $[12,13,15]$ or areas of several square kilometers $[12,17,18]$ and discrete geographical units including neighborhoods $[22,23]$ and urban parks [16]. The recognition of clustering of disease and islands of hyperendem-

\footnotetext{
Received 8 June 1998; revised 6 November 1998.

Financial support: This research was supported in part by an appointment of D.B.M. to the Emerging Infectious Diseases Fellowship Program administered by the Centers for Disease Control and Prevention and the Association of State and Territorial Public Health Laboratory Directors.

Reprints or correspondence: Dr. Timothy Jones, Tennessee Department of Health, CEDS, 4th Floor, Cordell Hull Building, 4255 th Avenue North, Nashville, Tennessee 37247 (tjones4@mail.state.tn.us)

Clinical Infectious Diseases 1999; 28:853-9

(C) 1999 by the Infectious Diseases Society of America. All rights reserved. 1058-4838/99/2804-0029\$03.00
}

icity is important for medical providers and public health personnel involved in treating and controlling the disease, because multiple infections can occur simultaneously or following identification of an index case.

\section{Case Report}

In August 1997, a previously well 49-year-old American Indian man from Tennessee presented to an emergency department in West Virginia, where he was traveling on business. He had a 5-day history of fever, headache, diffuse myalgias, and vomiting. The patient noted small red "chigger bites" around the ankles but recalled no recent tick bites. Physical examination revealed no identifiable source of infection, and no rash was noted. He was thought to have a viral illness and was discharged receiving symptomatic treatment. However, the symptoms increased, and 2 days later he was taken to a second hospital, where he presented with a temperature of $97.5^{\circ} \mathrm{F}$, blood pressure of 112/84 mm Hg, respirations of $20 / \mathrm{min}$, and pulse of $135 / \mathrm{min}$. He appeared ill with clammy, mottled skin.

Laboratory studies disclosed a normal WBC count of $9.4 \times$ $10^{9} / \mathrm{L}$, platelet count of $34 \times 10^{9} / \mathrm{L}$, partial thromboplastin time of 42.7 seconds (normal range, 22-32 seconds), prothrombin time of 12.6 seconds (normal range, 11-14 seconds), and creatinine level of $415 \mu \mathrm{mol} / \mathrm{L}(4.7 \mathrm{mg} / \mathrm{dL})$. Within hours of admission, the patient became increasingly tachypneic, developed seizures and ventricular fibrillation, and died. Conjunctival hemorrhage and lower extremity petechiae were observed at death. 
An autopsy revealed pulmonary edema, mild splenic congestion, acute tubular necrosis of the kidneys, and hepatomegaly, but otherwise no specific cause of death was found. Approximately 1 month after his death, PCR testing and immunohistochemical staining of tissue specimens that were performed at the Centers for Disease Control and Prevention (CDC) revealed $R$. rickettsii in the endothelium of organs including brain, spleen, liver, kidneys, heart, and lung. The Tennessee State Health Department was notified, precipitating an investigation.

Although the patient lived in a primarily urban county, his home was on a heavily wooded lot in a semirural area. In the days preceding his funeral and before discovery of the cause of death, friends and relatives from eight states congregated at his home. Many of these individuals participated in a 72-hour American Indian ceremonial fire on the patient's property. The day after the funeral, the index patient's wife was admitted to the hospital and diagnosed with RMSF. Several other friends and family members subsequently developed symptoms compatible with the disease and were treated presumptively for RMSF.

\section{Methods}

A questionnaire was administered to persons reported to have spent time at the patient's home during the week between his death and the time of his funeral. Information was collected on demographic variables, symptoms, treatment, and medical history. Questions were asked about participation in the ceremonial fire, eating or smoking outdoors, going into the woods, tick exposure, repellent use, and other activities and behaviors potentially related to the risk of contracting RMSF.

Serum samples were obtained from consenting participants, and these specimens were tested for IgG antibodies to $R$. rickettsii by an indirect immunofluorescence assay (IFA) at the CDC [24]. Initial serum specimens were obtained 6-10 weeks after the index patient's funeral. Patients with positive antibody titers were asked for a second serum specimen 4-6 weeks later. Pathological specimens were tested for the presence of spottedfever group (SFG) rickettsiae by using immunohistochemical staining [25] and PCR analysis. PCR products were sequenced and compared with known genetic sequences of rickettsiae [26].

A confirmed case of RMSF was defined as a clinically compatible illness (fever, headache, myalgia, or rash within 3 weeks of exposure) accompanied by a fourfold or greater change in the titer of antibody to $R$. rickettsii that was revealed by IFA testing of two separate serum specimens or by demonstration of SFG rickettsiae in a tissue specimen by immunohistochemical staining [27].

Ticks were collected from the index patient's home property and five similar control sites in the vicinity over a period of 2 successive days, 35 days after his funeral. The control sites included adjacent and nearby homes and properties within 3 miles that had similar vegetation, geography, pet ownership, and apparent use patterns. Flannel flags $\left(1 \mathrm{~m}^{2}\right)$ were dragged over low vegetation in wooded and grassy areas and the edges of driveways, roads, paths, and dwellings and were examined for ticks approximately every $10 \mathrm{~m}$. Ten $\mathrm{CO}_{2}$ traps were also placed near the index patient's home at $10-\mathrm{m}$ intervals along the perimeter of the yard for 6 hours. Ticks were identified and tested at the CDC for the presence of the rickettsial 17$\mathrm{kDa}$ gene by PCR analysis according to a modification of previously reported techniques [28] (D. B. McKechnie, J. Hatfield, J. W. Sumner, C. D. Paddock, J. Olson, and R. F. Massung, unpublished data).

Statistical analyses were performed by $\chi^{2}$ and Fisher's exact tests with use of Epi Info software [29].

\section{Results}

In addition to the index case, three confirmed cases of RMSF occurred after the funeral (table 1). Following the death of the index patient and before recognition of the cause of his death, his wife was the first person diagnosed with RMSF. The wife and brother of the index patient were both hospitalized because of severe febrile exanthematous illnesses within 2 weeks of the funeral. Both patients had a fourfold or greater rise in the titer of antibody to $R$. rickettsii. The index patient's sister developed a milder illness 2 weeks after the funeral and was treated successfully as an outpatient. A fourth seropositive individual, the son of the index patient, had evidence of antibody to $R$. rickettsii at a titer of $1: 64$, which persisted unchanged when retested 10 weeks later. He developed conjunctivitis and mild headache beginning 2 days after the funeral; his symptoms resolved without antibiotic therapy.

The investigation also identified another family member, a 13 month-old grandnephew of the index patient, who had died of RMSF 27 months before the index patient's funeral (table 1). The child had been living with the index patient's sister, $\sim 5$ miles from the index patient's home. He had spent time at the index patient's home before his death, although the family was unable to quantify this period and could recall no tick bites. Immunohistochemical staining of a tissue specimen that was obtained at autopsy of the child demonstrated SFG rickettsiae.

Fifty-five persons were identified as visitors or residents of the index patient's home during the week of his funeral. All but one (98\%) of these persons - $37(67 \%)$ of whom lived in one of eight states outside of Tennessee-responded to the questionnaire. Thirty-five persons $(65 \%)$ provided one or more serum specimens for testing; of these persons, 13 (37\%) lived in Tennessee, and $22(63 \%)$ lived in other states. After the wife's diagnosis, other family members were notified and urged to seek medical attention. Sixteen family members and friends of the index patient, all of whom spent time at his home during the week before his funeral, received doxycycline to either treat or avert RMSF. Fourteen of these persons were among those submitting serum specimens. Aside from the index patient's wife, brother, sister, and son who were mentioned above, none 
Table 1. Clinical characteristics of five patients associated with a cluster of cases of RMSF confirmed by serological testing or immunohistochemical analysis.

\begin{tabular}{|c|c|c|c|c|c|c|c|c|}
\hline \multirow[b]{2}{*}{$\begin{array}{l}\text { Age } \\
(y) / \text { sex }\end{array}$} & \multirow{2}{*}{$\begin{array}{l}\text { Relationship } \\
\text { to index } \\
\text { patient }\end{array}$} & \multirow[b]{2}{*}{ Date of onset } & \multirow[b]{2}{*}{$\begin{array}{l}\text { Predominant signs or } \\
\text { symptoms }\end{array}$} & \multicolumn{3}{|c|}{ Serum IFA titer } & \multirow[b]{2}{*}{$\begin{array}{l}\text { Antibiotic } \\
\text { therapy }\end{array}$} & \multirow[b]{2}{*}{ Outcome } \\
\hline & & & & $\begin{array}{c}\text { First } \\
\text { sample }\end{array}$ & $\begin{array}{l}\text { Second } \\
\text { sample }\end{array}$ & $\begin{array}{c}\text { Third } \\
\text { sample }\end{array}$ & & \\
\hline $49 / M$ & Index & 15 August 1997 & $\begin{array}{l}\text { Fever, headache, } \\
\text { myalgias, vomiting }\end{array}$ & NA & NA & NA & None & $\begin{array}{l}\text { Died; Rickettsia rickettsii } \\
\text { identified at autopsy by } \\
\text { immunohistochemical } \\
\text { analysis and PCR testing }\end{array}$ \\
\hline $50 / \mathrm{F}$ & Wife & 26 August 1997 & $\begin{array}{l}\text { Fever, headache, } \\
\text { myalgias, rash }\end{array}$ & $<1: 40^{*}$ & $1: 160^{*}$ & $1: 1,024$ & Doxycycline & $\begin{array}{l}\text { Well after 4-d } \\
\text { hospitalization }\end{array}$ \\
\hline $56 / \mathrm{M}$ & Brother & 8 September 1997 & $\begin{array}{l}\text { Headache, falling, rash, } \\
\text { hyponatremia, } \\
\text { thrombocytopenia }\end{array}$ & $<1: 64^{*}$ & $>1: 512^{*}$ & $1: 2,048$ & Doxycycline & $\begin{array}{l}\text { Well after 12-d } \\
\text { hospitalization }\end{array}$ \\
\hline $52 / \mathrm{F}$ & Sister & 11 September 1997 & $\begin{array}{l}\text { Headache, myalgias, } \\
\text { upper respiratory } \\
\text { tract symptoms, } \\
\text { cough }\end{array}$ & $1: 128$ & $1: 32$ & NA & Doxycycline & $\begin{array}{l}\text { Resolved with outpatient } \\
\text { treatment }\end{array}$ \\
\hline $1 / \mathrm{M}$ & Grandnephew & 11 May 1995 & $\begin{array}{l}\text { Rash, fever, vomiting, } \\
\text { diarrhea }\end{array}$ & $<1: 64^{*}$ & NA & NA & Chloramphenicol & $\begin{array}{l}\text { Died } 27 \text { mo before index } \\
\text { patient's funeral; } \\
\text { R. rickettsii identified at } \\
\text { autopsy by } \\
\text { immunohistochemical } \\
\text { analysis }\end{array}$ \\
\hline
\end{tabular}

NOTE. IFA = indirect immunofluorescent antibody; NA = not available; RMSF = Rocky Mountain spotted fever.

* Serum samples tested at laboratories other than the CDC.

of these persons had titers of antibody to $R$. rickettsii at or above the cutoff titer of 1:64.

When funeral attendees with titers of antibody to $R$. rickettsii of $\geqslant 1: 64$ were compared with those with titers of $<1: 64$, the presence of antibodies was associated with greater time spent at the family home during the week of the funeral, going into the woods surrounding the home, and being a first-degree relative of the index patient. Three of the five persons with evidence of recent or past infection with $R$. rickettsii resided at the index patient's home before his death. The ceremonial fire was attended by numerous persons for varying lengths of time, but the presence of antibodies to $R$. rickettsii was not correlated with length of time at the fire, collecting firewood, sitting on the ground, doing yard work, eating or smoking outside, not using insect repellents, noting a tick on one's body, or contact with the index patient's pet dog (who had not recently been ill).

Six hours of dragging flags yielded 133 ticks from the index patient's home property. In 12.5 hours of dragging flags at five control sites, only three ticks were collected. All ticks collected were identified as Amblyomma americanum (Lone Star tick) nymphs, except for one adult tick of the same species and a single Haemaphysalis leporispalustris (rabbit tick). PCR testing revealed the rickettsial $17-\mathrm{kDa}$ gene in 10 of 11 pools of ticks (each pool contained $\sim 13$ ticks). Gene sequencing of the PCR products showed that the ticks harbored Rickettsia amblyommii, a newly recognized Rickettsia species [30] not known to be pathogenic for humans.

\section{Discussion}

These data document a cluster of RMSF that occurred in a single family and suggest that the focus of $R$. rickettsii had persisted in the same location or vicinity for at least 2 years. Although RMSF is generally sporadic, family clusters of disease have been recognized for $>90$ years $[6-11,20,22,31-$ 63] (table 2). In some series, as many as $4 \%$ to $8 \%$ of all

Table 2. Previously reported family clusters of RMSF.

\begin{tabular}{|c|c|c|c|c|}
\hline Year(s) & State(s) & $\begin{array}{l}\text { No. of } \\
\text { family } \\
\text { members } \\
\text { in cluster }\end{array}$ & $\begin{array}{l}\text { No. of } \\
\text { clusters } \\
\text { reported }\end{array}$ & [Reference(s)] \\
\hline $1904-1987$ & $\begin{array}{l}\text { AL, IA, IL, MD, } \\
\text { MO, MS, MT, } \\
\text { NC, NJ, NY, } \\
\text { OH, RI, SC, } \\
\text { TN, TX, VA, } \\
\text { WV, WY, } \\
\text { Mexico }\end{array}$ & 2 & 51 & $\begin{array}{r}{[6-8,10,20} \\
22,31-61]\end{array}$ \\
\hline $1905-1973$ & $\begin{array}{c}\text { IA, MS, MT, } \\
\text { NC, WV, } \\
\text { Mexico }\end{array}$ & 3 & 9 & $\begin{array}{r}{[6,9,11,32,} \\
34,43,62]\end{array}$ \\
\hline 1931 & LA & 4 & 1 & [20] \\
\hline 1942 & $\mathrm{OK}$ & 6 & 1 & {$[20,63]$} \\
\hline
\end{tabular}

NOTE. $\quad$ RMSF $=$ Rocky Mountain spotted fever. 
Table 3. Reported geographic foci of RMSF in the United States.

\begin{tabular}{|c|c|c|c|c|}
\hline Location & Period & $\begin{array}{l}\text { No. of } \\
\text { cases* }\end{array}$ & Nature of focus & [Reference(s)] \\
\hline Wyoming & $1895-1915$ & NS & Cases clustered in two central counties & [33] \\
\hline Idaho & 1914 & 386 & Most cases clustered in six southern counties & [33] \\
\hline Bitterroot Valley, Montana & $1900-1980$ & 400 & Valley about 75 miles long & [32] \\
\hline Cape Cod, Massachusetts & $1955-1968$ & 30 & Cases concentrated in four areas on Cape Code and offshore islands & {$[12,18]$} \\
\hline Long Island, New York & $1961-1988$ & 59 & $\begin{array}{l}\text { Rate in East Hampton, Suffolk County, greater than that in other towns in } \\
\text { area (overlaps with focus below) }\end{array}$ & [64] \\
\hline Long Island, New York & $1971-1976$ & 124 & $\begin{array}{l}80 \% \text { of cases in New York during } 1941-1970 \text { occurred in Suffolk } \\
\text { County; concentrated } 2.2 \mathrm{~km} \text { from shoreline }\end{array}$ & {$[21,64]$} \\
\hline Clermont County, Ohio & $1962-1971$ & 85 & $94-\mathrm{km}^{2}$ area in a suburbanizing county & [13] \\
\hline Columbus, Ohio & $1966-1981$ & 28 & $\begin{array}{l}28 \text { cases in Franklin County occurred within } 2 \text { miles of this } 0.11-\mathrm{km}^{2} \\
(275 \text {-acre) area }\end{array}$ & [23] \\
\hline Ohio & 1981 & $\mathrm{~S}$ & Clermont, Franklin, and Lucas Counties (overlaps with two foci above) & {$[47,65]$} \\
\hline Virginia & 1969 & NS & Six counties in Piedmont plateau area with highest incidence & [66] \\
\hline North Carolina & $1970-1979$ & 12 & $\begin{array}{l}0.5 \text {-mile stretch of road in a small town in North Carolina, } 12 \text { cases in } 40 \\
\text { households over } 10 \mathrm{y}\end{array}$ & [22] \\
\hline Alabama & 1973 & 12 & "Highly endemic spotted fever area in northwest Alabama" & [67] \\
\hline Missouri & $1974-1984$ & 71 & $35 \%$ of cases in the state occurred in three counties & [68] \\
\hline Mississippi & $1975-1979$ & NS & $\begin{array}{l}\text { Two-thirds of cases occurred in } 14 \text { contiguous counties in the north and } \\
\text { northeast part of the state }\end{array}$ & [69] \\
\hline North Carolina & $1979-1981$ & NS & $\begin{array}{l}\text { Cabarrus and Rowan Counties; rate of RMSF four times that in North } \\
\text { Carolina and } 30 \text { times that in the U.S. }\end{array}$ & {$[15,70]$} \\
\hline Texas & $1979-1988$ & NS & Nine counties in north central Texas reporting $>10$ cases & [71] \\
\hline Tarrant County, Texas & 1983 & 8 & $6.4 \times 9.6-\mathrm{km}$ area where eight cases occurred in $2 \mathrm{mo}$ & [17] \\
\hline Oklahoma & $1981-1985$ & NS & Cases concentrated in 10 central counties & [72] \\
\hline South Carolina & $1985-1990$ & NS & Four counties with increased incidence & [73] \\
\hline New York City & 1987 & 4 & Near Soundview Park, Bronx & [16] \\
\hline Delaware & 1996 & 4 & Children at summer camp & [74] \\
\hline
\end{tabular}

NOTE. NS $=$ not specified; RMSF $=$ Rocky Mountain spotted fever.

patients with RMSF were part of family clusters [2, 22]. Similarly, the concepts of islands or foci of disease hyperendemicity have been noted previously (table 3 ) [12-23, 32, 33, 47, 6474]. Such foci have included areas of several square kilometers with persistently high rates of disease over periods of several years and rarely family members acquiring disease simultaneously. Our cluster apparently occurred from exposure around a single home.

The reasons for focal clustering of RMSF could include variable distribution of tick populations, focal areas of increased tick infection with $R$. rickettsii, increased rickettsial virulence or host susceptibility, new incursions of humans into tick-infested areas, or a combination of these factors. The potential of dogs as a possible reservoir of $R$. rickettsii is debated [75], and in this study, direct contact with the family dog was not correlated with disease. $R$. rickettsii is passed transovarially from adult females to their progeny; therefore, foci may be expected to occur. Several studies have estimated that $\leqslant 1 \%$ of ticks may carry pathogenic $R$. rickettsii even in areas of endemicity $[65,76]$. Although some studies have not found differences in distribution of infected ticks related to rates of disease $[12,13,77-79]$, other investigators have noted a correlation $[16,21,65]$.
In the eastern United States, the primary vector of $R$. rickettsii is Dermacentor variabilis (American dog or wood tick) [4]. Whether the Lone Star tick $A$. americanum also transmits the disease is debated [3, 4, 67]. Many of the people interviewed in this study described large numbers of small, pinpoint-sized brown "seed ticks" at the home and on their bodies, and other persons denied tick bites but noted numerous itchy red "chigger bites" around the ankles. Seed ticks are the small, six-legged larval stage of hard ticks, including $A$. americanum, and these ticks can be difficult to see and identify. Some reports suggest that larval $A$. americanum ticks are capable of biting humans and transmitting $R$. rickettsii [80], which may account for some cases of RMSF without a recognized history of tick bite [81].

Only $A$. americanum ticks were collected from the index patient's property in this study, although collection did not occur until 5 weeks after his death. Possibly, the tick population had changed in the 5-week interval between his death and collection, and $D$. variabilis was the vector in this cluster but was not present at the time of collection. The patient's property was heavily wooded, with habitat that would support populations of both species. No obvious factors were apparent to account for the clustering of ticks at the index site, compared 
with the remarkably lower rate of tick collection from adjacent properties.

This investigation used PCR analysis and gene sequencing to identify rickettsiae; $R$. amblyommii was found, but there was no evidence of $R$. rickettsii. The PCR technique amplified and allowed specific identification of DNA from the predominant rickettsial species in the tick pools. The sensitivity of the technique is not known. Possibly, lower levels of $R$. rickettsii were present in this tick population but went undetected by this method.

Only seven of the 16 persons in this investigation who were treated empirically for RMSF had any type of rash. Previous studies of RMSF suggest that the characteristic rash may be absent in $5 \%$ to $34 \%$ of patients $[2-4,64,82]$ and that only one-half may have a rash within the first 3 days [82]. Lack of a rapid diagnostic test for RMSF necessitates treatment based on the history and results of physical examination plus a high index of suspicion. Only three (21\%) of the 14 symptomatic persons treated presumptively from whom serum samples were available had antibodies to $R$. rickettsii at titers of $>1: 64$. It has been reported that treatment with antibiotics within the first few days of disease onset may blunt the development of antibodies detectable by $\mathrm{CF}$ and microagglutination testing [83-86] but that other tests are less affected [85]. This phenomenon has not been extensively studied with the IFA test.

One person who provided serum samples but was not treated for RMSF had a titer of IgG antibody to $R$. rickettsii of 1:64, which was unchanged when tested again 10 weeks later. $\mathrm{He}$ often worked in the woods near the family home and had a long history of frequent tick bites; however, he had never been diagnosed with RMSF and could not recall a specific illness suggestive of the disease. This case may represent a stable, persistent antibody titer from a previous asymptomatic or unrecognized infection with $R$. rickettsii or possibly another SFG Rickettsia. Serosurveys have revealed detectable titers of antibody to SFG rickettsiae in $11 \%$ to $21 \%$ of sixth graders $[17,87]$ and $29 \%$ of adults in areas of endemicity [70]. The existence of asymptomatic infections is debated [4], although the lack of specificity of symptoms makes unrecognized mild infections likely.

This cluster is a salient example of the importance of considering RMSF in the differential diagnosis of patients with febrile illnesses who present in the spring and summer in areas of endemicity. Prophylactic treatment of asymptomatic persons exposed to ticks is not recommended [88, 89], even in areas where RMSF is endemic. However, because of a lack of specific symptoms or a rapid diagnostic test, empirical treatment of persons with suspected cases is often necessary. Although Ricketts [1] long ago noted their "rare occurrence," family clusters and hyperendemic foci of RMSF may be more common than appreciated. When a case of RMSF is suspected, it is important for family members and physicians to remain vigilant for signs or symptoms consistent with $R$. rickettsii infection in other persons who may have been similarly exposed.

\section{Acknowledgments}

The authors thank William Farthing, M.D., for identifying the index patient; Stanley J. Bodner, M.D., for diagnosing and treating one of the patients; Joseph Singleton, Jr. (CDC), for performing rickettsial serologies; Stephanie Eberhardy, P.A.-C., for assistance with specimen collection and patient follow-up; James Cooper for assistance with tick collection; and Laura J. Fehrs, M.D. (Epidemiology Program Office, CDC), for her thoughtful review of the manuscript.

\section{References}

1. Ricketts HT. Some aspects of Rocky Mountain spotted fever as shown by recent investigations. Medical Record 1909;76:903-5.

2. Hattwick MA, O'Brien RJ, Hanson BF. Rocky Mountain spotted fever: epidemiology of an increasing problem. Ann Intern Med 1976;84: $732-9$.

3. Dalton MJ, Clarke MJ, Holman RC. National surveillance for Rocky Mountain spotted fever, 1981-1992: epidemiologic summary and evaluation of risk factors for fatal outcome. Am J Trop Med Hyg 1995; 52: 405-13.

4. Weber DJ, Walker DH. Rocky Mountain spotted fever. Infect Dis Clin North Am 1991;5:19-35.

5. Centers for Disease Control and Prevention. Summary of notifiable diseases, United States, 1996. MMWR Morb Mortal Wkly Rep 1996; 45:52.

6. Sexton DJ, Burgdorfer W. Clinical and epidemiologic features of Rocky Mountain spotted fever in Mississippi, 1933-1973. South Med J 1975; 68:1529-35.

7. Schaffner W, McLeod AC, Koenig MG. Thrombocytopenic Rocky Mountain spotted fever-case study of a husband and wife. Arch Intern Med $1965 ; 116: 857-65$

8. Bradford WD. Rocky Mountain spotted fever. Clin Pediatr (Phila) 1979; 18:634-5.

9. Sanders DY, Smithson WA. Rocky Mountain spotted fever in three brothers. N C Med J 1973;34:276-8.

10. Jacobs WM. Rocky Mountain spotted fever in an infant. Am J Dis Child 1978; 132:928-9.

11. Stroy HE. Rocky Mountain spotted fever-report of three simultaneous cases in one family. Journal of the Iowa State Medical Society 1937; 27:293-4.

12. Massachusetts Department of Health. On the alert for Rocky Mountain spotted fever. N Engl J Med 1975;292:1127-9.

13. Linneman CC, Schaeffer AE, Burgdorfer W, Hutchinson L, Philip RN. Rocky Mountain spotted fever in Clermont County, OH-II. Distribution of population of infected ticks in an endemic area. Am J Epidemiol 1980; $111: 31-6$.

14. Benach JL, Smith LA, White DJ. An example of geographic clustering of Dermocentor variabilis adults infected with rickettsiae of the spotted fever group. In: Burgdorfer W, Anacker RL, eds. Rickettsiae and rickettsial diseases. New York: Academic Press, 1981:611-8.

15. Durack DT. Rus in urbe-spotted fever comes to town. N Engl J Med 1988; 318:1388-90.

16. Salgo MP, Telzak EE, Currie B, et al. A focus of Rocky Mountain spotted fever within New York City. N Engl J Med 1988;318:1345-8.

17. Taylor JP, Tanner WB, Rawlings JA. Serological evidence of subclinical Rocky Mountain spotted fever infections in Texas. J Infect Dis 1985; 151:367-9.

18. Hazard GW, Ganz RN, Nevin RW. Rocky Mountain spotted fever in the United States: thirteen cases from the Cape Cod area of Massachusetts. N Engl J Med 1969;280:57-61.

19. Walker DH, Fishbein DB. Epidemiology of rickettsial diseases. Eur J Epidemiol 1991;7:237-41. 
20. Parker RR, Kohls GM, Steinhaus EA. Rocky Mountain spotted fever: spontaneous infection in the tick Amblyomma americanum. Public Health Rep 1943; 19:721-9.

21. Benach JL, White DJ, Burgdorfer W, Keelan T, Guirgis A, Altieri RH. Changing patterns in the incidence of Rocky Mountain spotted fever on Long Island (1971-1976). Am J Epidemiol 1977; 106:380-7.

22. Kaplowitz LG, Fischer JJ, Sparling PF. Rocky Mountain spotted fever: a clinical dilemma. Curr Clin Top Infect Dis 1981;2:80-108.

23. Smith RC, Gordon JC, Gordon SW, Philip RN. Rocky Mountain spotted fever in an urban canine population. J Am Vet Med Assoc 1983;183: $1451-3$.

24. Philip RN, Casper EA, Ormsbee RA, Peacock MG, Burgdorfer W. Microimmunofluorescence test for the serological study of Rocky Mountain spotted fever and typhus. J Clin Microbiol 1976;3:51-61.

25. Zaki SR, Greer PW, Coffield LM, et al. Hantavirus pulmonary syndrome: pathogenesis of an emerging infectious disease. Am J Pathol 1995; 146 : $552-79$.

26. Staden R. The STADEN package. Methods Mol Biol 1994;25:9-170.

27. Centers for Disease Control and Prevention. Case definitions for infectious conditions under public health surveillance. MMWR Morb Mortal Wkly Rep 1997; 46:28-9.

28. Tzianabos T, Anderson BE, McDade JE. Detection of Rickettsia rickettsii DNA in clinical specimens using polymerase chain reaction technology. J Clin Microbiol 1989;27:2866-8.

29. Dean AD, Dean JA, Coulombier D, et al. Epi Info. Version 6: a word processing, database and statistics program for epidemiology on microcomputers. Atlanta: Centers for Disease Control and Prevention, 1994

30. Pretzman C, Stohard DR, Ralph D, Fuerst PA. A new species of Rickettsia, isolated from the lone star tick, Amblyomma americanum (Ixodidae). In: Program and abstracts of the 11th sesquiannual meeting of the American Society for Rickettsiology and Rickettsial Diseases. St. Simons Island, GA: American Society for Rickettsiology and Rickettsial Diseases, 1994:24.

31. Wilson LB, Chowning WM. Studies in Pyroplasmosis hominis ("spotted fever" or "tick fever" of the Rocky Mountains). J Infect Dis 1904; 1 : 31-57.

32. Ashburn PM. Piroplasmosis hominis (?): spotted fever of Montana. LancetClinic 1905; 54:481-94

33. Fricks LD. Rocky Mountain spotted fever: a report of its investigation and of measures undertaken for its eradication during 1914. Public Health Rep 1915; 30:148-65.

34. Rumreich A, Dyer RE, Badger LF. The typhus-Rocky Mountain spotted fever group: an epidemiological and clinical study in the eastern and southeastern states. Public Health Rep 1931;46:470-80.

35. Litterer W. Rocky Mountain spotted fever (eastern type) in the southern states. South Med J 1933;26:407-15.

36. Bierring W. Rocky Mountain spotted fever. Journal of the Iowa State Medical Society 1942;32:222-3.

37. Maillard ER, Hazen EL. Rocky Mountain spotted fever in New York State outside of New York City. Am J Public Health 1935;25:1015-7.

38. Pons CA, DePons SC, Sweet WA. Rocky Mountain spotted fever. J Med Soc N J 1938; 35:666-70.

39. Jordan CF. Rocky Mountain spotted fever and tick survey in Iowa. Am J Public Health 1938;28:1411-8.

40. Pearson JS. Rocky Mountain spotted fever; a report of two fatal cases. West Virginia Medical Journal 1940;36:26-8.

41. James GW, Walker H. Para-amino benzoic acid in the treatment of Rocky Mountain spotted fever. Virginia Medical Monthly 1947;74:161-7.

42. Bustamante ME, Varela G. Characteristics de la fiebre manchada de las Montanas Rocosas en Sonora y Sinaloa, Mexico. Revista del Instituto de Salubridad y Infermedades Tropicales 1944;5:129-34.

43. Tichenor CJ, Ross S, McLendon PA. Rocky Mountain spotted fever: a preliminary report on the use of para-aminobenzoic acid. J Pediatr 1947; $31: 1-23$.
44. Carson MJ, Gowen LF, Cochrane FR. Rocky Mountain spotted fever treated with chloromycetin. J Pediatr 1949;35:232-4.

45. Edwards EH, Irwin WH, Holley HL. Chloromycetin therapy in Rocky Mountain spotted fever; report of two cases. Journal of the Medical Association of Alabama 1949; 19:165-6.

46. Casford RS. Rocky Mountain spotted fever: report of two cases. Journal of the Missouri State Medical Association 1943;40:171.

47. Gordon JC, Gordon SW, Peterson E, Philip RN. Epidemiology of Rocky Mountain spotted fever in Ohio, 1981: serologic evaluation of canines and rickettsial isolation from ticks associated with human case exposure sites. Am J Trop Med Hyg 1984;33:1026-31.

48. Bradshaw v Daniel. 854 SW2d 865 (Tenn. 1993).

49. Anonymous. Rocky Mountain spotted fever. Md Med J 1988;37:253-6.

50. Baker GE. Rocky Mountain spotted fever. JAMA 1943;122:841-50.

51. Milam DF. Rocky Mountain spotted fever in North Carolina. South Med J 1934;27:788-92.

52. Floyd ML. Rocky Mountain spotted fever: report of four Iowa cases. Journal of the Iowa State Medical Society 1937;27:294-6.

53. Montz F. Rocky Mountain spotted fever. Journal of the Iowa State Medical Society 1936;26:614-7.

54. McLaughlin EA, Grover EI. Rocky Mountain spotted fever in Rhode Island. Rhode Island Medical Journal 1937;20:139-43.

55. Meade TS. Rocky Mountain spotted fever. Virginia Medical Monthly 1946; 73:216-8.

56. Maulitz RM, Imperato PL. Rocky Mountain spotted fever in urban setting. NY State J Med 1974;74:1403-4.

57. Darby CP. The jury and Rocky Mountain unspotted fever [guest editorial]. J SC Med Assoc 1983;79:451.

58. Bierring W. Three cases of spotted fever reported in Iowa. Journal of the Iowa State Medical Society 1943;33:307.

59. Hassin GB. Cerebral changes in Rocky Mountain spotted fever. Archives of Neurological Psychiatry 1940;44:1290-5.

60. deBorja C, Hrehorovich VR. Rocky Mountain spotted fever: often a diagnostic dilemma. Md Med J 1991;40:367-70.

61. Walker DH, Burday MS, Folds JD. Laboratory diagnosis of Rocky Mountain spotted fever. South Med J 1980;73:1443-6.

62. Preston DG. Rocky Mountain spotted fever, eastern type: three cases occurring in same family on the western decline of the Alleghenies. West Virginia Medical Journal 1934;30:119-22.

63. Sizemore P. Rocky Mountain spotted fever. Journal of the Oklahoma State Medical Association 1943;36:282-5.

64. White DJ, Flynn MK. Rocky Mountain spotted fever in New York State. Ann NY Acad Sci 1990; 590:248-55.

65. Pretzman C, Daugherty N, Poetter K, Ralph D. The distribution and dynamics of rickettsia in the tick population of Ohio. Ann NY Acad Sci 1990; $590: 227-36$.

66. Peters AH. Tick-borne typhus (Rocky Mountain spotted fever); epidemiologic trends, with particular reference to Virginia. JAMA 1971;216: 1003-7.

67. Burgdorfer W. A review of Rocky Mountain spotted fever (tick-borne typhus), its agent, and its vectors in the United States. J Med Entomol 1975; 12:269-78

68. Dolan SA, Everett ED, Satalawicz FT. Rocky Mountain spotted fever in Missouri. Mo Med 1986;83:321-5.

69. Wiygul FM. Rocky Mountain spotted fever in Mississippi: an update on an increasingly common infection. J Miss State Med Assoc 1981;22: $143-5$.

70. Wilfert CM, MacCormack JN, Kleeman K, et al. The prevalence of antibodies to Rickettsia rickettsii in an area endemic for Rocky Mountain spotted fever. J Infect Dis 1985;151:823-31.

71. Elliott LB, Fournier PV, Teltow GJ. Rickettsia in Texas. Ann NY Acad Sci 1990;590:221-6.

72. Taylor JP, Istre GR, McChesney TC. The epidemiology of Rocky Mountain spotted fever in Arkansas, Oklahoma, and Texas, 1981 through 1985. Am J Epidemiol 1988; 127:1295-301. 
73. Smathers BR, Jones JL, Sy FS, Meyer P. Epidemiology of Rocky Mountain spotted fever in South Carolina, 1985-1990. J SC Med Assoc 1992; 88:378-85.

74. Rotz L, Callejas L, McKechnie D, et al. An epidemiologic and entomologic investigation of a cluster of Rocky Mountain spotted fever cases in Delaware. Del Med J 1998; 70:285-91.

75. Norment BR, Burgdorfer W. Susceptibility and reservoir potential of the dog to spotted fever group rickettsiae. Am J Vet Res 1984;45:1706-10.

76. Burgdorfer W. Ecological and epidemiological considerations of Rocky Mountain spotted fever. In: Walker DH, ed. Biology of rickettsial diseases. Boca Raton, Florida: CRC Press, 1988:33-50.

77. Sacks JJ, Pinner TAF, Parker RL. Tick testing as a method of controlling Rocky Mountain spotted fever. Am J Public Health 1983;73:903-5.

78. Loving SM, Smith AB, DiSalvo AF, Burgdorfer W. Distribution and prevalence of spotted fever group rickettsiae in ticks from South Carolina, with an epidemiological survey of persons bitten by infected ticks. Am J Trop Med Hyg 1978;27:1255-60.

79. Magnarelli LQ, Anderson JF, Philip RN, Burgdorfer W, Casper EA. Endemicity of spotted fever group rickettsiae in Connecticut. Am J Trop Med Hyg 1981;30:715-21.

80. Duckworth PF, Gerloff RK. Human infestation by Amblyomma americanum larvae ("seed ticks"). South Med J 1985; 78:751-3.
81. Culp JS. Seed ticks. Am Fam Physician 1987;36:121-3.

82. Helmick CG, Bernard KW, D'Angelo LJ. Rocky Mountain spotted fever: clinical, laboratory, and epidemiological features of 262 cases. J Infect Dis 1984; $150: 480-8$.

83. Lackman DB, Gerloff RK. The effects of antibiotic therapy upon diagnostic, serologic tests for Rocky Mountain spotted fever. Public Health Laboratory 1953;11:97-100.

84. Schubert JH. Serologic titers in rickettsial infection as affected by antibiotic treatment. Public Health Laboratory 1952; 10:38-41.

85. Kaplan JE, Schonberger LB. The sensitivity of various serologic tests in the diagnosis of Rocky Mountain spotted fever. Am J Trop Med Hyg 1986;35:840-4.

86. Philip RN, Casper EA, MacCormack JN, et al. A comparison of serologic methods for diagnosis of Rocky Mountain spotted fever. Am J Epidemiol 1977; 105:56-67.

87. Marx RS, McCall CE, Abramson JS, Harlan JE. Rocky Mountain spotted fever; serological evidence of previous subclinical infection in children. Am J Dis Child 1982;136:16-8.

88. Kenyon RH, Williams RG, Oster CN, Pederson CE. Prophylactic treatment of Rocky Mountain spotted fever. J Clin Microbiol 1978;8:102-4.

89. Walker DH. Rocky Mountain spotted fever: a seasonal alert. Clin Infect Dis 1995;20:1111-7. 